\title{
ANALISIS FAKTOR PEMBEDA DANA CADANGAN HAJI DAN ARRUM HAJI
}

\author{
Astried Rosalina Faradita Putri ${ }^{*}$ \\ Universitas Singaperbangsa Karawang \\ Wirman \\ Universitas Singaperbangsa Karawang
}

\begin{abstract}
Hajj is one of the main activities that must be done by Muslims as a form of practice in order to increase piety to the Creator. This Hajj Arrum product can be a solution for people who do not have sufficient costs for the pilgrimage. Prior to the existence of the Hajj arrum product, Islamic banks had already issued a product to finance people who wanted to go to Hajj which was known as the Hajj bailout fund. However, there are pros and cons because it is considered contrary to the Fatwa of the National Sharia Council Number: 29 / DSN-MUI / VI / 2002 concerning the Financing of Hajj Management for Sharia Financial Institutions. Actually the hajj pilgrimage is not enforced, but based on the community's ability, it is hoped that with this hajj arrum people can immediately perform the haj pilgrimage. However, people still have to be careful before choosing a product. Therefore, the authors want to know the factors that distinguish the products that have been circulating previously, namely the Hajj bailout. This research was conducted using secondary and qualitative methods. It can be concluded that the Hajj arrum product by sharia pawnshops is in accordance with the provisions of the Indonesian Ulema Council (MUI)

Keywords: Hajj, Hajj Bailout, Hajj Arrum
\end{abstract}

Paper type: Research paper

*Corresponding author: $1810631030120 @$ student.unsika.ac.id

Received: January 28, 2021; Accepted: November 13, 2021; Available online: December, 04, 2021

Cite this document:

Putri, A. R., \& Munaraja, W. (2021). Analisis Faktor Pembeda Dana Cadangan Haji dan Arrum Haji. Jurnal Masharif Al-Syariah: Jurnal Ekonomi dan Perbankan Syariah, 6(3), 648-669. doi:http://dx.doi.org/10.30651/jms.v6i3.7304

Copyright @ 2021, Jurnal Masharif Al-Syariah: Jurnal Ekonomi dan Perbankan Syariah http://journal.um-surabaya.ac.id/index.php/Mas/index

This article is licensed under a Creative Commons Attribution-NonCommercial 4.0 International License. 


\begin{abstract}
Abstrak
Haji merupakan salah satu kegiatan pokok yang harus dilakukan oleh umat Islam sebagai bentuk amalan guna meningkatkan ketakwaan kepada Sang Pencipta. Produk arrum haji ini bisa menjadi solusi bagi masyarakat yang belum mempunyai biaya yang cukup untuk beribadah haji. Sebelum adanya produk arrum haji, bank syariah telah lebih dulu mengeluarkan produk guna membiayai masyarakat yang ingin berangkat haji yang dikenal dengan dana talangan haji. Namun terdapat pro kontra karena dianggap bertentangan dengan Fatwa Dewan Syariah Nasional Nomor: 29/DSN-MUI/VI/2002 Tentang Pembiayaan Pengurusan Haji Lembaga Keuangan Syariah. Sebenernya Ibadah haji tidak dipaksakan namun berdasarkan kemampuan masyarakat sehingga diharapkan dengan adanya arrum haji ini masyarakat dapat segera menunaikan ibadah haji. Namun, masyarakat tetap harus berhati-hati sebelum memilih suatu produk. Oleh karenanya, penulis ingin mengetahui faktor yang membedakan Produk Arrum Haji produk yang telah beredar sebelumnya yaitu dana talangan haji. Penelitian ini dilakukan dengan metode sekunder dan kualitatif. Dapat diambil kesimpulan bahwa produk arrum haji oleh pegadaian syariah sudah sesuai dengan ketentuan dari Majelis Ulama Indonesia (MUI).

Kata kunci: Haji, Dana Talangan Haji, Arrum Haji
\end{abstract}

\title{
PENDAHULUAN
}

Pada zaman dahulu, manusia hanya mengenal sistem bercocok tanam. Sehingga petani hanya bisa memakan padi, peternak memakan hewan, nelayan memakan ikan. Pada waktu itu manusia menjadi makhluk nomaden yang artinya tidak memiliki tempat tinggal yang tetap karena selalu berpindahpindah tempat. Hal ini dikarenakan habisnya persediaan alam, kalah dalam peperangan antar suku, faktor alam dan lain sebagainya. Hingga pada akhirnya, petani bertemu dengan peternak, nelayan dan yang lainnya. Karena kebutuhan yang belum tercukupi akhirnya mendorong mereka untuk saling menukar kebutuhan yang dikenal dengan nama barter. Petani dapat menukarkan padi hasil bertanamnya dengan ikan yang dibawa nelayan, dan sebaliknya. Dengan adanya sistem barter ini, terdapat banyak sekali keuntungan karena kebutuhan masing-masing dapat terpenuhi. Namun disisi lain juga terdapat kekurangan dari sistem barter ini antara lain yaitu tidak 
adanya alat ukur yang tepat. Jika dianalogikan apakah seimbang apabila $5 \mathrm{~kg}$ padi ditukar dengan 5 ekor ikan. Selain itu, sulit untuk mencari orang yang barangnya dapat ditukar dengan barang kebutuhan kita. Dari segi waktu pula diharuskan untuk masing-masing orang menyerahkan barangnya dengan barang kebutuhan orang lain pada waktu yang dibutuhkan. Tentu hal ini amatlah susah karena harus mencari orang dan barang yang kita butuhkan. Kemudian manusia memikirkan solusi untuk memecahkan masalah ini yaitu dengan diciptakannya satuan nilai ukur dalam bentuk barang.

Barang yang digunakan pada awalnya hanya yang terbuat dari bahan alam seperti batu, kerang, kemudian semakin berkembang hingga bahan yang digunakan yaitu logam seperti besi, perak, timah, kuningan, emas, dan sebagainya. Hasil dari bahan-bahan tersebut diubah menjadi suatu barang yang dapat ditukar sesuai dengan kebutuhan sehingga pada masa ini dikenal dengan nama uang barang (Wulan, 2016). Dengan adanya uang barang, kendala yang sebelumnya mulai teratasi. Tidak harus menunggu orang dengan kebutuhan yang sama untuk bisa saling menukar. Hal ini lah yang menandai munculnya uang sebagai alat tukar yang sah.

Dari beberapa barang yang dijadikan sebagai alat tukar tersebut ditemukan beberapa permasalahan seperti bentuk fisiknya yang berat sehingga cukup susah untuk dibawa kemana-mana. Selain itu, karena barang logam seperti emas, perak, tembaga merupakan barang yang susah dicari dan jumlahnya terbatas hingga suatu hari nanti bisa habis karena termasuk sumberdaya yang tidak dapat diperbarui. Berawal dari masalah tersebut muncul ide untuk menciptakan uang dari bahan alam yang mudah dan ringan dan ditemukanlah bahan baku yang cocok yaitu kayu sehingga terciptalah uang kertas yang dipakai hingga saat ini. Dipilihnya bahan dasar kayu karena lebih ringan dan bisa diperbaharui. Setelah munculnya uang kertas, penggunaan uang logam pun semakin sedikit dan hanya digunakan untuk pecahan dengan nilai yang kecil. Dengan adanya uang sebagai alat tukar mendorong adanya lembaga yang bertugas untuk menyimpan dana dari 
masyarakat. Lembaga keuangan adalah semua perusahaan/institusi/organisasi dibidang keuangan yang didalamnya melakukan kegiatan penghimpunan dana dari masyarakat dan mengelola dana yang ada untuk kemudian disalurkan kembali sebagai pembiayaan kepada masyarakat. Dana dari kegiatan tersebut dapat digunakan untuk memenuhi kebutuhan produksi, distribusi ataupun konsumsi. Lembaga keuangan dapat diklasifikasikan dalam beberapa golongan. Berdasarkan sistem yang digunakannya terdapat 2 jenis lembaga keuangan yaitu lembaga keuangan dengan sistem konvensional dan lembaga keuangan dengan sistem syariah.

\section{METODE PENELITIAN}

Metode yang digunakan dalam penulisan ini adalah metode penelitian kualitatif yaitu metode yang menghasilkan laporan yang banyak mengandung deskripsi. Isi dari laporan tersebut bukan berupa angka, melainkan berupa pandangan penulis terhadap suatu masalah (Musianto, 2002). Data yang digunakan berasal dari studi kepustakaan yang bukan berasal dari wawancara atau penelitian secara langsung. Dalam metode ini, data yang digunakan berasal dari sumber sekunder yaitu yang diperoleh dari dokumen resmi seperti Undang-undang, Keputusan Pemerintah, jurnal penelitian yang telah dilakukan sebelumnya serta website resmi lembaga keuangan dan non keuangan.

\section{PEMBAHASAN}

\section{Lembaga Keuangan}

Menurut Latumaerissa, Lembaga keuangan adalah badan usaha yang kekayaannya terutama berbentuk aset keuangan (financial assets) atau tagihan (claims) dibandingkan dengan aset non keuangan (non financial assets) (Julius R, 2017).

Menurut Undang-undang Nomor 14 Tahun 1967 yang kemudian diganti dengan Pasal 1 Undang-undang Nomor 7 Tahun 1992 Tentang Perbankan menjelaskan pengertian lembaga keuangan yaitu suatu badan atau lembaga 
yang aktivitasnya untuk menarik hasil dana dari masyarakat yang kemudian disalurkan kepada masyarakat kembali.

Dari kedua pengertian diatas, dapat disimpulkan bahwa lembaga keuangan adalah suatu badan yang bergerak di bidang keuangan dimana didalamnya melakukan aktivitas mengumpulkan dana dari masyarakat untuk dikelola hingga kemudian disalurkan kepada masyarakat kembali. Lembaga keuangan berdasarkan aktivitasnya dapat dibagi menjadi lembaga keuangan yang berbentuk bank yaitu Lembaga Perbankan dan Lembaga Keuangan Bukan Bank (LKBB).

Tabel 1. Perbedaan Utama Bank dan Lembaga Keuangan Bukan Bank

\begin{tabular}{|c|c|c|}
\hline Kegiatan & \multicolumn{2}{|c|}{ Lembaga Keuangan } \\
\hline & Bank & Bukan Bank \\
\hline Penghimpunan dana & $\begin{array}{l}\text { 1. Secara langsung } \\
\text { yaitu dalam bentuk } \\
\text { simpanan dana } \\
\text { masyarakat } \\
\text { (tabungan, giro, } \\
\text { deposito), dan } \\
\text { 2. Secara tidak } \\
\text { langsung dari } \\
\text { masyarakat yaitu } \\
\text { dalam bentuk kertas } \\
\text { berharga, } \\
\text { penyertaan, } \\
\text { pinjaman atau kredit } \\
\text { dari lembaga lain }\end{array}$ & $\begin{array}{l}\text { Hanya secara tidak } \\
\text { langsung } \\
\text { masyarakat dari } \\
\text { melalui } \\
\text { berharga, dan bisa juga } \\
\text { dari penyertaan, pinjam } \\
\text { atau kredit dari } \\
\text { lembaga lain) }\end{array}$ \\
\hline Penyaluran dana & $\begin{array}{l}\text { 1. Untuk tujuan modal } \\
\text { kerja, investasi, } \\
\text { konsumsi } \\
\text { 2. Kepala badan usaha } \\
\text { dan individu } \\
\text { 3. Untuk jangka } \\
\text { pendek, menengah, } \\
\text { dan paniana }\end{array}$ & $\begin{array}{l}\text { 1. Terutama untuk } \\
\text { tujuan investasi } \\
\text { 2. Terutama kepada } \\
\text { badan usaha } \\
\text { 3. Terutama untuk } \\
\text { jangka menengah } \\
\text { dan panjang }\end{array}$ \\
\hline
\end{tabular}

Sumber: utamisantoso dan Nuritomo (2017)

Dari tabel tersebut dapat diketahui mengenai perbedaan yang mendasar keduanya. Lembaga Keuangan Bank merupakan lembaga yang bertugas menghimpun dana dari masyarakat baik secara langsung seperti tabungan 
maupun secara tidak langsung seperti dengan adanya surat berharga, sedangkan lembaga keuangan Bukan Bank hanya secara tidak langsung dapat menghimpun dana dari masyarakat yaitu dalam bentuk kertas berharga . Berdasarkan fungsinya (Rinaldi, 2017), lembaga keuangan bank terdiri dari Bank sentral yaitu Bank Indonesia, Bank Umum dan Bank Perkreditan Rakyat. Sedangkan Lembaga Keuangan Bukan Bank adalah lembaga selain Bank seperti: pegadaian, koperasi, pasar modal, pasar uang dan lain sebagainya.

\section{Lembaga Keuangan Bank}

Berdasarkan UU No 10 Tahun 1998 yang menggantikan UU No 7 Tahun 1992 Tentang Perbankan, Bank adalah badan usaha yang menghimpun dana dari masyarakat dalam bentuk simpanan dan menyalurkannya kepada masyarakat dalam bentuk kredit dan atau bentuk-bentuk lainnya dalam rangka meningkatkan taraf hidup rakyat banyak. Menurut jenisnya, bank terdiri dari:

1. Bank Umum adalah bank yang melaksanakan kegiatan usaha secara konvensional dan atau berdasarkan Prinsip Syariah. Bank umum bertugas untuk menghimpun dana dari masyarakat dalam bentuk simpanan, memberikan kredit, dan kegiatan lain dalam hal pembiayaan. Namun bank umum tidak boleh melakukan penyertaan modal, melakukan usaha perasuransian, dan usaha lain diluar usaha yang diperbolehkan. 


\section{Gambar 1. Grafik Jumlah kantor Bank Umum di Indonesia}

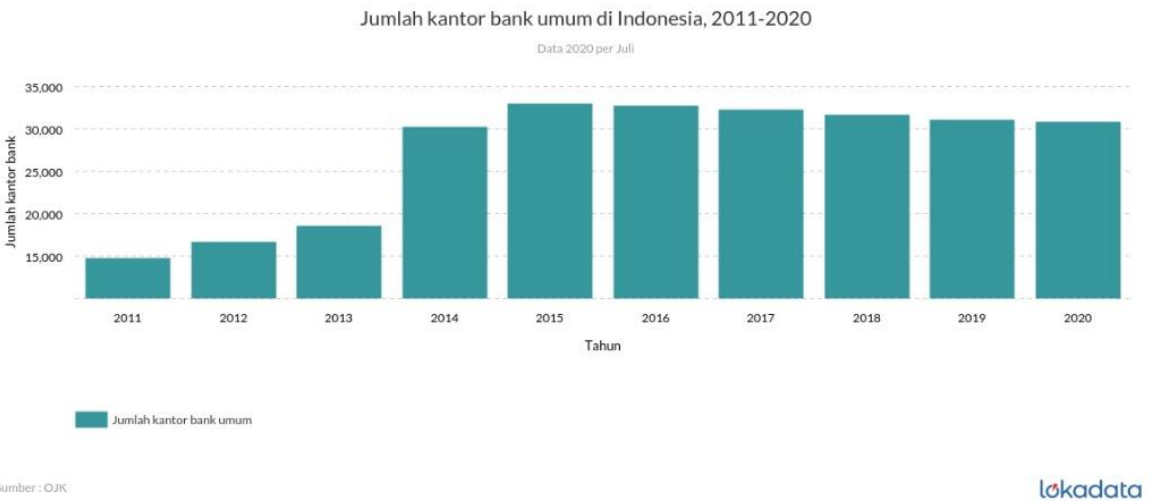

\section{Sumber: Lokadata}

Dari grafik tersebut dapat diketahui di tahun 2011, kantor bank umum yang terdapat di Indonesia belum mencapai 15.000 kantor. Pada tahun 2012 mengalami kenaikan hingga melebihi 15.000 kantor. Jumlah kantor bank tertinggi terdapat di tahun 2015. Namun sejak tahun 2015 jumlah kantor bank di Indonesia mengalami penurunan sehingga berdasarkan data terlihat bahwa jumlah kantor bank per Juli 2020 yaitu sebesar 30.893 kantor.

2. Bank Perkreditan Rakyat adalah bank yang melaksanakan kegiatan usaha secara konvensional atau berdasarkan Prinsip Syariah yang dalam kegiatannya tidak memberikan jasa dalam lalu lintas pembayaran. Usaha Bank Perkreditan Rakyat meliputi:

i. menghimpun dana dari masyarakat dalam bentuk simpanan berupa deposito berjangka, tabungan, dan/atau bentuk lainnya yang dipersamakan dengan itu;

ii. memberikan kredit;

iii. menyediakan pembiayaan bagi nasabah berdasarkan prinsip bagi hasil sesuai dengan ketentuan yang ditetapkan dalam Peraturan Pemerintah; 
iv. menempatkan dananya dalam bentuk Sertifikat Bank Indonesia (SBI), deposito berjangka, sertifikat deposito dan/atau tabungan pada bank lain.

Namun BPR dilarang menerima simpanan berupa giro, melakukan kegiatan usaha valuta asing, melakukan penyertaan modal, usaha perasuransian dan usaha lain diluar usaha yang diatur pada Undangundang Republik Indonesia Nomor 10 Tahun 1998 Tentang Perbankan.

\section{Lembaga Keuangan Bukan Bank}

Lembaga Jasa Keuangan Non Bank yang selanjutnya disebut LJKNB adalah lembaga yang melaksanakan kegiatan di sektor perasuransian, dana pensiun, lembaga pembiayaan, dan lembaga jasa keuangan lainnya. LKJNB tersebut meliputi (POJK, No. 24, 2019):

1. Perusahaan perasuransian. Menurut Undang-Undang Republik Indonesia Nomor 40 Tahun 2014 Tentang Perasuransian Asuransi adalah perjanjian antara dua pihak, yaitu perusahaan asuransi dan pemegang polis, yang menjadi dasar bagi penerimaan premi oleh perusahaan asuransi sebagai imbalan untuk memberikan penggantian kepada tertanggung ataupun pemegang polis karena kerugian atau memberikan pembayaran yang didasarkan pada meninggalnya tertanggung. Terdiri dari: perusahaan asuransi, perusahaan reasuransi baik yang menyelenggarakan dengan sisstem konvensional maupun syariah, perusahaan pialang asuransi termasuk perusahaan pialang reasuransi.

2. Dana pensiun adalah badan hukum yang mengelola dan menjalankan program yang menjanjikan manfaat pensiun. Didalam Undang-Undang Nomor 11 Tahun 1992 tentang Dana Pensiun dijelaskan bahwa manfaat pensiun adalah pembayaran berkala yang dibayarkan kepada peserta pada saat dan cara yang telah diatur sebelumnya. 
3. Lembaga pembiayaan, terdiri atas: perusahaan pembiayaan dengan prinsip syariah maupun konvensional, perusahaan modal ventura baik dengan prinsip konvensional maupun syariah, serta perusahaan pembiayaan infrastruktur.

4. Lembaga jasa keuangan lainnya:

i. perusahaan pergadaian. Gadai adalah suatu kontrak antara kedua pihak yang mana terdapat orang yang berhutang yang akan menyerahkan barang yang ia miliki sebagai jaminannya.

ii. lembaga penjamin

iii. penyelenggara layanan pinjam meminjam uang berbasis teknologi informasi

iv. lembaga pembiayaan ekspor Indonesia

v. perusahaan pembiayaan sekunder perumahan

vi. badan penyelenggara jaminan sosial

vii. PT Permodalan Nasional Madani (Persero)

\section{Haji}

Haji merupakan salah satu rukun Islam. Haji artinya perjalanan ke suatu tempat tertentu pada waktu yang telah ditentukan dalam rangka ibadah kepada Allah SWT. Semua orang dari seluruh penjuru dunia berlomba-lomba untuk menunaikan haji demi menyempurnakan rukun Islam. Namun ada beberapa ketentuan yang membatasi kuota untuk pemberangkatan haji karena jumlah pendaftar haji yang meningkat setiap tahunnya. Jumlah haji yang diberangkatkan dari Indonesia menuju Mekah (Arab Saudi) dapat dilihat pada tabel berikut (BPS): 
Tabel 2. Jamaah Haji dari Indonesia

\begin{tabular}{|r|l|}
\hline \multicolumn{1}{|c|}{ Tahun } & Jumlah Jamaah \\
\hline 2007 & 188.569 \\
\hline 2008 & 191.823 \\
\hline 2009 & 189.358 \\
\hline 2010 & 196.206 \\
\hline 2011 & 199.849 \\
\hline 2012 & 192.291 \\
\hline 2013 & 154.546 \\
\hline 2014 & 154.467 \\
\hline 2015 & 154.455 \\
\hline 2016 & 154.441 \\
\hline Total & 1.776 .005 \\
\hline
\end{tabular}

\begin{tabular}{|l|l|} 
Rata-rata & 177.601 \\
\hline Tertinggi & 199.849 \\
\hline Terendah & 154.441 \\
\hline
\end{tabular}

\section{Gambar 2. Grafik Jumlah Jamaah Haji}

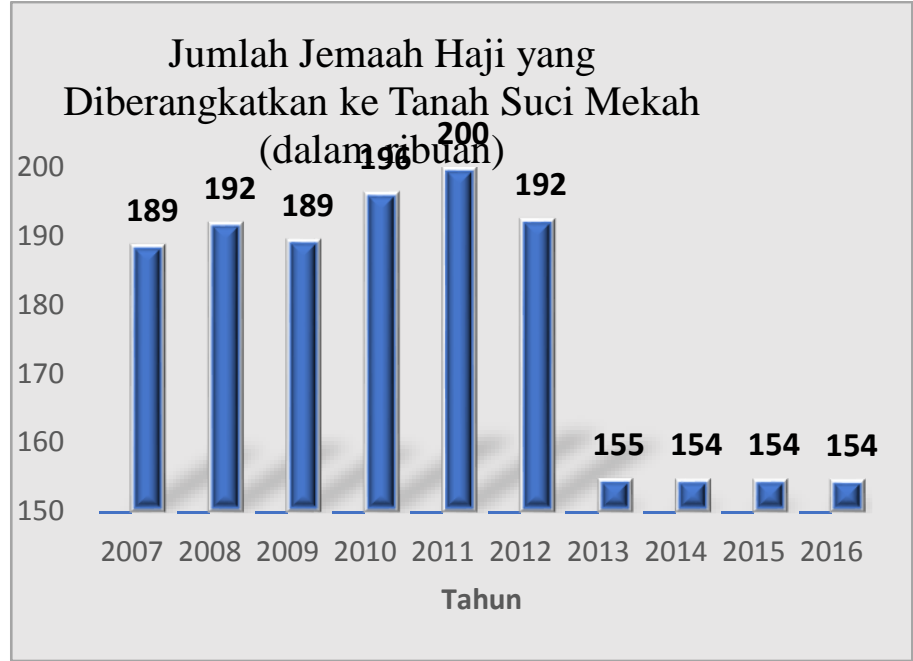

Sumber : BPS. Data diolah oleh penulis

Dari data yang diperoleh dari website resmi BPS, kemudian penulis mengolah data tersebut dan membuatnya dalam bentuk grafik, dapat dilihat bahwa jumlah jamaah haji dari Indonesia yang berangkat ke Mekah (Arab Saudi) mulai tahun 2007 hingga 2016 yaitu sebesar 1.776 .005 orang. Jumlah jamaah terbanyak terjadi pada tahun 2011 yaitu sebesar 199.849 orang, sedangkan jumlah jamaah paling sedikit terdapat pada tahun 2016 yaitu sebesar 154.441 orang. 
Syarat wajib haji:

1. Islam.

Orang yang mengerjakan haji wajib beragama Islam. Ibadah tidak sah dari orang kafir. Apabila ada orang yang bukan Islam namun ingin menunaikan haji, maka orang itu harus mengucapkan syahadat terlebih dahulu agar bisa masuk Islam. Berdasarkan firman Allah:

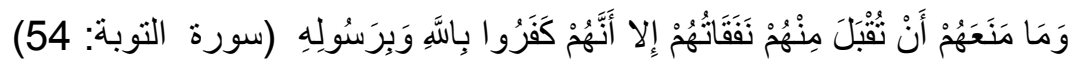
"Dan tidak ada yang menghalangi mereka untuk diterima dari mereka nafkah-nafkahnya melainkan karena mereka kafir kepada Allah dan RasulNya." (QS. At-Taubah: 54)

2. Berakal. Berakal artinya sadar terhadap apa yang ia lakukan. Adapun orang yang menderita penyakit gangguan jiwa tidak bisa dikatakan sebagai orang yang berakal karena ia tidak mengetahui dan tidak sadar terhadap apa yang ia lakukan.

3. Baligh

Baligh adalah fase dimana seseorang telah dianggap dewasa, apabila perempuan sudah mendapati datang bulan(menstruasi) sedangkan pada laki-laki apabila sudah pernah mengalami mimpi basah. Seseorang yang sudah dikatakan baligh sudah bisa membedakan mana hal boleh dilakukan dan tidak boleh dilakukan. Sehingga anak kecil tidak diwajibkan untuk berhaji, tetapi jika terdapat wali yang ingin menghajikannya maka hukum haji itu adalah sah dan memberikan pahala bagi anak dan wali tersebut. Berdasarkan sabda Nabi sallallahu'alaihi wa sallam ketika ada seorang wanita yang bertanya kepada beliau "Apakah anak ini dapat melakukan haji? Beliau menjawab, "Ya, dan bagimu mendapat pahala." (HR. Muslim)

4. Merdeka. Merdeka artinya tidak dalam pengaruh siapapun. Seorang pelayan atau yang bisa disebut budak tidak harus pergi berhaji, karena dia harus melakukan kewajibannya yaitu melayani tuannya. 
5. Mampu. Allah berfirman :

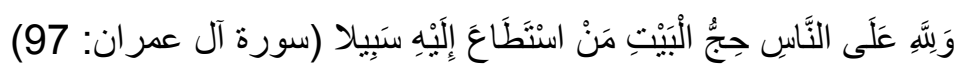

Yang artinya "Mengerjakan haji adalah kewajiban manusia terhadap Allah, yaitu (bagi) orang yang sanggup mengadakan perjalanan ke Baitullah." (QS. Ali Imran: 97). Maksud dari kata sanggup disini adalah mampu secara fisik dan mampu secara finansial. Mampu secara fisik artinya berbadan sehat dan sanggup untuk melaksanakan seluruh urutan ibadah haji. Mampu secara finansial artinya memiliki biaya perjalanan yang cukup untuk sampai ke tempat yang dituju dan untuk membiayai pengeluaran selama ibadah tersebut.

\section{Pro kontra Dana Talangan Haji}

Keputusan Direktur Jenderal Penyelenggaraan Haji dan Umrah Nomor 117 Tahun 2019 Tentang Petunjuk Pelaksanaan Pembayaran Biaya Penyelenggaraan Ibadah Haji Reguler Tahun 1440H/2019M menetapkan kuota haji reguler sebanyak 204.000. Sementara, Kementerian Agama dan Komisi VIII DPR RI menyetujui Biaya Penyelenggaraan Ibadah Haji (BPIH) Tahun $1441 \mathrm{H} / 2020 \mathrm{M}$ atau biaya yang dibayar langsung oleh jemaah senilai Rp35.235.602 dari total biaya seluruhnya untuk keberangkatan haji mencapai Rp 72 juta/jemaah. Nominal itu sama dengan BPIH pada 2019 dan 2018 lalu (Faisol, 2020). Menurut Peraturan Menteri Agama Republik Indonesia Nomor 30 Tahun 2013 Tentang Bank Penerima Setoran Biaya Penyelenggaraan Ibadah Haji, BPIH adalah sejumlah dana yang harus dibayar oleh warga negara yang akan menunaikan ibadah haji. BPS BPIH adalah bank syariah dan/ bank umum nasional yang memiliki layanan syariah. Pembayaran pelunasan $\mathrm{BPIH}$ dapat dilakukan pada tempat berikut:

1. Bank Jabar Banten (BJB), BJB Unit Usaha Syariah (BJBS), dan BPD DIY pelunasannya dilakukan melalui BNI Syariah

2. BPD Kalsel, BPD Kaltim dan BPD NTB pelunasannya dilakukan melalui BSM 
3. BPD Sulselbar dan BPD Sultra pelunasannya dilakukan melalui Bank Muamalat Indonesia

4. Bank Bukopin pelunasannya dilakukan melalui Bank Mega Syariah

\section{Gambar 3. Indeks Kepuasan Jemaah Haji Indonesia INDEKS KEPUASAN JEMAAH HAJI INDONESIA TAHUN 1440H/2019M}

\section{PERKEMBANGAN IKJHI 2014-2019}

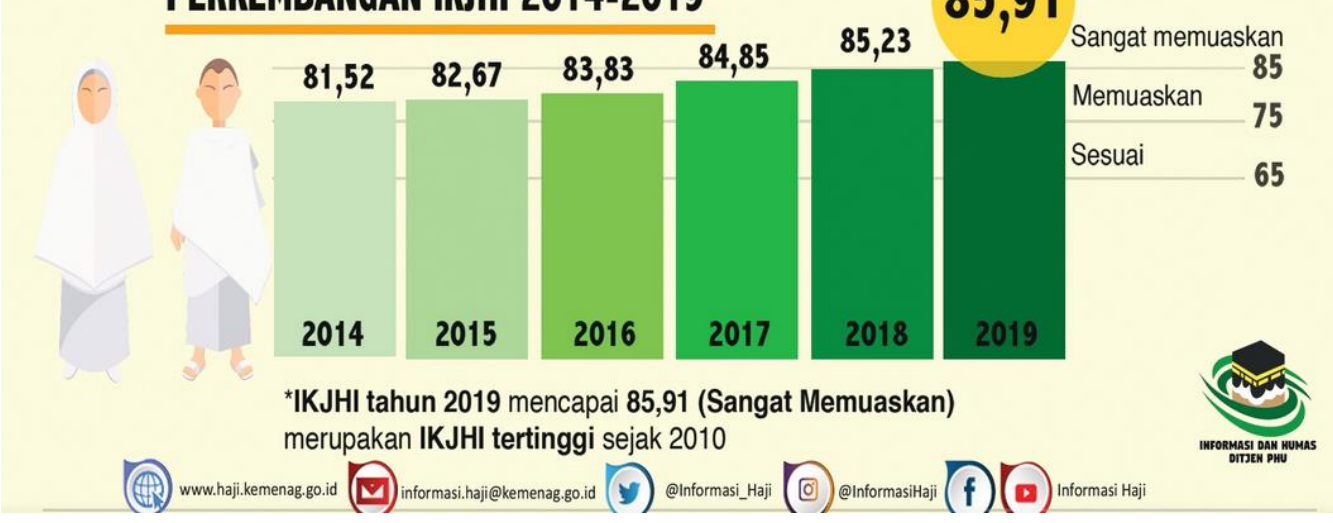

Sumber: Kemenag

Dari data diatas dapat dilihat bahwa Indeks Kepuasan Jemaah Haji Indonesia semakin taun semakin meningkat. Sejak tahun 2014 angka IKJHI menunjukkan 81,52 yang masih dalam tahap memuaskan. Angka IKJHI tertinggi terdapat pada tahun 2019 yaitu sebesar 85,91 dan sudah berada di tingkat sangat memuaskan. Hal itu bisa dikarenakan pelayanan yang semakin baik tiap tahunnya, informasi yang semakin cepat didapat, proses pendaftaran yang semakin mudah dan lain sebagainya yang membuat jamaah merasa senang terhadap ibadah yang telah dijalaninya.

Dalam Peraturan Menteri Agama Republik Indonesia Nomor 30 Tahun 2013 diatur mengenai dana talangan haji yaitu dana yang diberikan sebagai bantuan sementara tanpa mengenakan imbalan oleh BPS BPIH kepada calon jemaah haji. Tujuan adanya dana talangan haji adalah untuk mempermudah nasabah dalam berhaji dengan menyerahkan sejumlah uang tertentu sebagai setoran kemudian bank akan memberikan pinjaman kepada nasabah tersebut untuk menutupi kekurangan dana guna mendapatkan kursi haji. Sementara, 
bagi pihak Perbankan, adanya dana talangan haji diharapkan dapat meningkatkan jumlah nasabah. Dana talangan ini dijamin dengan deposit yang dimiliki nasabah. Nasabah kemudian wajib mengembalikan sejumlah uang yang dipinjam itu dalam jangka waktu tertentu dari total BPIH (Biaya Perjalanan Ibadah Haji). Atas jasa peminjaman dana talangan ini, bank Syariah memperoleh imbalan (fee/ujrah) yang besarnya tidak boleh didasarkan pada jumlah dana yang dipinjamkan.

Dana talangan haji ini seperti yang diluncurkan oleh pertama kali oleh Bank Syariah Mandiri pada 3 Mei 2000 namun pada 2018 dana talangan haji ini dilarang oleh pemerintah yang diatur pada Peraturan Menteri Agama Republik Indonesia Nomor 8 Tahun 2018 Tentang Penyelenggaraan Perjalanan Ibadah Umrah. Hal ini dikarenakan dana talangan haji dianggap:

i. Membatalkan syarat wajib haji yaitu mampu.

Mampu yang dimaksud disini adalah mampu secara finansial. Karena hanya dengan sejumlah uang tertentu dapat digunakan untuk mendapatkan kursi haji sehingga hal ini akan menggeser orang yang benar-benar mampu namun belum mendaftar.

ii. Menambah antrean

Dengan banyaknya orang yang telah mendapatkan kursi haji walaupun menggunakan dana talangan maka akan semakin menambah antrean karena setiap daerah dibatasi kuota haji per tahun sedangkan pendaftar haji semakin bertambah banyak.

iii. Adanya ujrah/fee

Setiap lembaga perbankan didirikan bertujuan untuk kegiatan ekonomi yaitu mendapatkan keuntungan dari jasa tersebut. Begitu pula dengan bank yang memberikan dana talangan haji mengharuskan nasabahnya untuk membayar fee atas jasa pendaftaran kursi haji.

iv. Adanya 2 akad yang digunakan dalam suatu objek, yakni ijarah dan qard 
Terdapat ketentuan dalam teori bisnis dengan prinsip syariah, yaitu adanya larangan bahwa dalam 1 objek tidak boleh menggunakan 2 akad sekaligus. Hal ini dipertegas dengan hadist berikut:

Larangan Nabi Shallallahu 'alaihi wa sallam "Tidak halal menggabungkan antara piutang dengan akad jual-beli" [HR Abu Dawud hadits no. 3506 dan At-Tirmidzy hadits no. 1234].

Pada dana talangan haji terdapat 2 objek, yakni uang dan jasa pengurusan kursi haji, sehingga diperlukan 2 akad pula untuk masingmasing objek tersebut yakni qard(piutang) untuk uang dan ijarah untuk layanan dan harus dipisahkan agar tetap mengandung konsep bisnis syariah. Dari ilustrasi tersebut dapat dilihat bahwa bank telah menggabungkan kedua akad tersebut yaitu piutang dengan sewa menyewa.

v. Mengajak masyarakat untuk berhutang

Banyak masyarakat yang memaksakan diri untuk pergi berhaji dengan dana talangan karena dengan menyerahkan uang muka saja sudah mendapatkan kursi haji. Namun masyarakat tetap harus melunasi kewajiban tersebut sehingga pasti akan menambah beban pikiran masyarakat. Hal yang memaksakan diri tersebut tidak baik terutama menyalahi syarat wajib haji yaitu mampu.

\section{Arrum haji}

Arrum haji telah diluncurkan oleh pegadaian syariah sejak Desember 2016 (Lestari, 2018). Arrum haji adalah pembiayaan untuk mendapatkan kursi haji dengan proses mudah, cepat dan aman. Produk Arrum Haji merupakan inovasi produk dana talangan haji yang sebelumnya telah dikeluarkan oleh bank syariah.

Namun terdapat hal yang membedakan diantara kedua produk tersebut seperti yang telah dirangkum pada tabel berikut: 


\begin{tabular}{|c|c|c|}
\hline Karakteristik & Arrum haji & Dana talangan haji \\
\hline $\begin{array}{l}\text { Lembaga keuangan } \\
\text { syariah }\end{array}$ & Pegadaian syariah & Bank syariah \\
\hline Akad & Ar rahn & $\begin{array}{l}\text { Gabungan } 2 \text { akad yaitu } \\
\text { akad qardh (piutang) } \\
\text { dan ijarah(jasa sewa) }\end{array}$ \\
\hline Dasar hukum & $\begin{array}{lr}\text { Fatwa } & \text { No.92/DSN- } \\
\text { MUI/IV/2014 } & \text { tentang } \\
\text { Pembiayaan } & \text { Yang } \\
\text { Disertai Rahn } & \end{array}$ & $\begin{array}{l}\text { Fatwa DSN MUI Nomor } \\
\text { 29/DSN-MUI/VI/2002 } \\
\text { Tentang Pembiayaan } \\
\text { Pengurusan } \\
\text { Lembaga Haji } \\
\text { Syariah }\end{array}$ \\
\hline
\end{tabular}

Menurut penulis, produk arrum haji dan dana talangan haji memiliki persamaan dan perbedaan. Persamaan keduanya terletak pada aspek tujuan yaitu untuk membantu masyarakat mendapatkan kursi haji dengan cara memberikan pinjaman. Adapun perbedaan kedua produk tersebut terdapat pada aspek:

\section{Dasar hukum}

Dana talangan haji berpedoman pada Fatwa DSN MUI Nomor 29/DSN$\mathrm{MUI} / \mathrm{VI} / 2002$ Tentang Pembiayaan Pengurusan Haji Lembaga Keuangan Syariah. Isi dan penjelasan dari Fatwa tersebut sebagai berikut:

1. Dalam pengurusan haji bagi nasabah, LKS dapat memperoleh imbalan jasa (ujrah) dengan menggunakan prinsip al-ljarah sesuai Fatwa DSNMUI nomor 9/DSN-MUI/IV/2000

Imbalan jasa/ujrah/upah adalah sesuatu yang dijanjikan dan dibayar nasabah kepada LKS sebagai pembayaran manfaat dan nasabah memiliki kewajiban membayar sewa atau upah dan bertanggung jawab untuk menjaga keutuhan barang serta menggunakannya sesuai kontrak.

2. Apabila diperlukan, LKS dapat membantu menalangi pembayaran BPIH nasabah dengan menggunakan prinsip al-Qardh sesuai Fatwa DSN-MUI nomor 19/DSN-MUI/IV/2001.

Al-Qardh adalah pinjaman yang diberikan kepada nasabah (muqtaridh) yang memerlukan. Nasabah al-Qardh wajib 
mengembalikan jumlah pokok yang diterima pada waktu yang telah disepakati bersama ditambah dengan biaya administrasi yang dibebankan kepada nasabah. LKS dapat pula meminta jaminan kepada nasabah.

3. Jasa pengurusan haji yang dilakukan LKS tidak boleh dipersyaratkan dengan pemberian talangan haji.

Pada dasarnya diperbolehkan adanya ujrah dalam dana talangan haji. Namun harus dipisahkan antara akad-akad yang digunakan seperti akad qard(piutang) dan ijarah (ujrah/fee). Hal inilah yang menjadikan perdebatan karena didalam dana talangan haji tersebut terdapat ketentuan adanya sesuatu yang dijanjikan dan dibayar nasabah kepada LKS sebagai pembayaran manfaat.

4. Besar imbalan jasa al-ljarah tidak boleh didasarkan pada jumlah talangan al-Qardh yang diberikan LKS kepada nasabah.

Terdapat beberapa perbankan syariah yang menawarkan ujrah/fee berdasarkan waktu pembayaran maupun jumlah pinjaman. Hal itulah yang menyebabkan dilarangnya ujrah karena dianggap memanfaatkan ujrah dari lamanya pengembalian dari nasabah sebagai pendapatan bank tersebut.

Sedangkan arrum haji berpedoman pada Fatwa No.92/DSN-MUI/IV/2014 tentang Pembiayaan Yang Disertai Rahn. Isi dari fatwa tersebut antara lain : Semua bentuk pembiayaan/penyaluran dana Lembaga Keuangan Syariah (LKS) boleh dijamin dengan agunan (Rahn) sesuai ketentuan dalam fatwa ini. Barang jaminan (marhun) harus berupa harta (mal) berharga baik benda bergerak maupun tidak bergerak yang boleh dan dapat diperjual-belikan, termasuk aset keuangan berupa sukuk, efek syariah atau surat berharga syariah lainnya. Dalam hal ini berarti pembiayaan pinjaman haji dengan barang jaminan emas diperbolehkan.

Akad Rahn berakhir apabila Rahin melunasi utangnya atau menyelesaikan kewajibannya dan Murtahin mengembalikan Marhun(jaminan) 
kepada Rahin. Namun apabila Rahin tidak dapat melunasi kewajibannya, murtahin boleh menjual paksa barang jaminan tersebut atau meminta rahin untuk menyerahkan jaminan tersebut.

\section{Lembaga Keuangan Syariah yang mengeluarkan produk tersebut}

Perbankan syariah mengeluarkan produk yaitu dana talangan haji. Menurut data yang dilansir dari Otoritas Jasa Keuangan (OJK), Bank Syariah adalah Bank yang menjalankan kegiatan usahanya berdasarkan Prinsip Syariah yaitu prinsip hukum Islam dalam bidang perbankan berdasarkan fatwa yang dikeluarkan oleh lembaga yang berwenang yaitu Majelis Ulama Indonesia serta peraturan lain yang masih berlaku hingga saat ini. Perbankan syariah di Indonesia terdiri atas:

1. Bank Umum Syariah (BUS) adalah Bank Syariah yang dalam kegiatannya memberikan jasa dalam lalu lintas pembayaran.

2. Unit Usaha Syariah (UUS) adalah unit kerja dari kantor pusat Bank Umum Konvensional yang berfungsi sebagai kantor induk dari kantor atau unit yang melaksanakan kegiatan usaha berdasarkan Prinsip Syariah, ataupun unit kerja di kantor cabang dari suatu Bank yang berkedudukan di luar negeri yang melaksanakan kegiatan usaha secara konvensional yang berfungsi sebagai kantor induk dari kantor cabang pembantu syariah dan/ unit syariah

3. Bank Pembiayaan Rakyat Syariah (BPRS).

Hingga bulan Juni 2019, jumlah bank syariah di Indonesia berjumlah 189 yang terdiri dari 14 Bank Umum Syariah (BUS), 20 Unit Usaha Syariah (UUS), dan 164 Bank Pembiayaan Rakyat Syariah (BPRS). Angka ini kemungkinan akan terus bertambah mengingat kebutuhan dan pengetahuan manusia semakin bertambah yang disesuaikan dengan perkembangan zaman.

Arrum haji merupakan produk dari pegadaian syariah. Syarat untuk mendaftar arrum haji adalah: Memenuhi syarat sebagai pendaftar haji, menyerahkan Foto copy KTP, menyerahkan Foto copy KK, disertai 
dengan jaminan emas batangan (LM) minimal 3,5 gr atau emas perhiasan dengan kadar minimal $70 \%$ dengan berat sekitar 7 gram. Produk arrum haji ini dapat diberikan kepada nasabah dengan minimal uang pinjaman sebesar $R p$ 1.900.000 dan maksimal Rp 25.000.000 yang disertai biaya administrasi sebesar Rp 270.000 dengan jangka waktu pinjaman 1-5 tahun. Berikut merupakan tatacara pengajuan arrum haji dilansir dari web pegadaian digital:

1. Siapkan syarat dan ketentuan yang diperlukan dalam pengajuan Pembiayaan Arrum Haji

2. Silahkan datang pada outlet atau cabang Pegadaian terdekat untuk mengajukan permohonan pembiayaan Arrum Haji

3. Menyerahkan Marhun Emas kepada pegadaian untuk proses penaksiran oleh Pegadaian

4. Mengisi formulir permohonan pembiayaan Arrum Haji

5. Mendatangi Pihak Bank untuk memperoleh dokumen SABPIH dari bank

6. Mendatangi kantor kemenag untuk memproses dan memperoleh Nomor Porsi / SPPH

7. Menyerahkan SABPIH, SPPH, Buku Tabungan ke Pegadaian

\section{Akad yang digunakan}

Dana talangan haji menggunakan akad al qardh yaitu dengan cara memberikan sejumlah dana untuk menutupi kekurangan dana nasabah guna melakukan ibadah haji. Adapun akad ijarah adalah LKS dapat memperoleh imbalan jasa (ujrah) namun yang harus diperhatikan adalah terdapat beberapa bank syariah yang menetapkan fee/ujrah berdasarkan jumlah pinjaman. Hal ini bertentangan dengan Fatwa Dewan Syari'ah Nasional Nomor: 29/DSNMUI/VI/2002 Tentang Pembiayaan Pengurusan Haji Lembaga Keuangan Syari'ah mengenai "Besar imbalan jasa al-ljarah tidak boleh didasarkan pada jumlah talangan al-Qardh yang diberikan Lembaga Keuangan Syariah kepada nasabah." 
Dalam arrum haji , dana yang diberikan nasabah bukan merupakan dana talangan namun dianggap sebagai pinjaman yang diberikan kepada nasabah yang dijamin oleh barang dari nasabah itu sendiri yaitu berupa emas. Dalam hal ini sudah sesuai dengan ketentuan dari Fatwa Dewan Syariah Nasional Nomor:92/DSN-MUI/IV/2014 Tentang Pembiayaan Yang Disertai Rahn mengenai "Barang jaminan (marhun) harus berupa harta (mal) berharga baik benda bergerak maupun tidak bergerak yang boleh dan dapat diperjualbelikan,termasuk aset keuangan berupa sukuk, efek syariah atau surat berharga syariah lainnya." Utang boleh dalam bentuk uang dan/ barang dan tidak boleh bertambah karena adanya perpanjangan waktu pembayaran. Ketentuan terkait dengan akad rahn pada fatwa tersebut yaitu "pada prinsipnya , akad rahn dibolehkan hanya atas utang-piutang (al-dain) yang antara lain timbul karena akad qardh , jual-beli (al-bai') yang tidak tunai ,atau akad sewamenyewa (ijarah) yang pembayaran ujrahnya tidak tunai". Berdasarkan ketentuan ini akad yang digunakan dalam arrum haji sudah sesuai dengan fatwa yang dikeluarkan oleh Majelis Ulama Indonesia (MUI).

\section{KESIMPULAN}

Lembaga keuangan adalah suatu badan yang bergerak di bidang keuangan dan bertugas untuk menghimpun kekayaan dari masyarakat untuk disalurkan kepada masyarakat kembali. Pegadaian tergolong dalam lembaga jasa keuangan bukan bank. Terdapat pegadaian dengan sistem konvensional dan syariah. Arrum haji termasuk dalam produk dari pegadaian syariah yang diminati masyarakat. Dalam penjelasan diatas, dapat disimpulkan bahwa akad yang dipakai dalam produk arrum haji sudah sesuai dengan ketentuan Fatwa No.92/DSN-MUI/IV/2014 tentang Pembiayaan Yang Disertai Rahn. Namun, alangkah lebih baik apabila menunaikan haji/umrah bukan dengan dana pinjaman karena berhutang akan menjadi beban pikiran yang baru akan dihapuskan hutangnya pada saat hutang tersebut dibayar. Hal itu sejalan dengan pendapat para ulama, yaitu mendahulukan melunasi hutangnya daripada melakukan ibadah haji. 


\section{DAFTAR PUSTAKA}

Faisol, Amir. 2020. "DPR RI dan Pemerintah Sepakat Biaya Haji 2020 Tak Naik", dalam Pikiran Rakyat 31 Januari 2020

Fatwa DSN-MUI Nomor 9/DSN-MUI/IV/2000 Tentang al-ljarah

Fatwa DSN-MUI Nomor 19/DSN-MUI/IV/2001 Tentang al-Qardh

Fatwa DSN MUI Nomor 29/DSN-MUI/VI/2002 Tentang Pembiayaan Pengurusan Haji Lembaga Keuangan Syariah

Fatwa DSN MUI Nomor 92/DSN-MUI/IV/2014 tentang Pembiayaan Yang Disertai Rahn

http:// www.syariahmandiri.co.id/category/.../pembiayaan-talangan-haji/ yang dilansir dari Bab III Dana Talangan Haji Universitas Islam Negeri Sunan Ampel Surabaya

Ihwan Saputra, "Analisis Pembiayaan Pada Produk Ar-Rum Haji Di Pegadaian Syariah Kantor Cabang Banda Aceh" , (Skripsi S1 Fakultas Ekonomi Dan Bisnis Islam Universitas Islam Negeri Ar-Raniry Banda Aceh , 2018)

Julius R. Latumaerissa , "Bank dan Lembaga Keuangan Lain Teori dan Kebijakan", Jakarta : Mitra Wacana Media , 2017

Keputusan Direktur Jenderal Penyelenggaraan Haji dan Umrah Nomor 117 Tahun 2019 Tentang Petunjuk Pelaksanaan Pembayaran Biaya Penyelenggaraan Ibadah Haji Reguler Tahun 1440H/2019M Maret 2018

Lestari, Reni. 2018. "Pegadaian Syariah Rilis Dua Produk Baru”, 5

Luthfina, Aulia. "Implementasi Fatwa DSN-MUI Pada Produk Arrum Haji Di Pegadaian Syariah Cabang Babakan Surabaya". Jurnal Ekonomi Syariah Teori dan Terapan. Volume 06. Nomer 12 2019. Surabaya

Musianto, Lukas. "Perbedaan Pendekatan Kuantitatif dengan Pendekatan Kualitatif dalam Metode Penelitian". Jurnal Ekonomi Manajemen. Volume 4 . Nomer 2. September 2002. Hal 123-136

Peraturan Otoritas Jasa Keuangan Nomor 24/POJK.05/2019 Tentang Rencana Bisnis Lembaga Jasa Keuangan Non Bank 
Puli Parisan, "Eksistensi Produk Dana Talangan Haji Dalam Peningkatan Jumlah Calon Haji Di Kabupaten Padanglawas Sumatera Utara" , (Tesis S2 Universitas Islam Negeri Sultan Syarif Kasim Riau, 2013)

Rinaldi. 2017.

"Lembaga

Keuangan"

http://ilmuekonomi123.blogspot.com/2017/05/lembaga-keuangan.html

(diakses 13 Januari 2021)

Syarat Wajib Haji https://islamqa.info/id/answers/41957/syarat-wajib-haji (diakses 18 Januari 2021)

Tri, Eri. 2020. Sejarah dan Perkembangan Bank Syariah di Indonesia. https://blog.amartha.com/sejarah-dan-perkembangan-bank-syariah-diindonesia/ (diakses 16 Januari 2021)

Venny Andrianingtias, "Analisis Pembiayaan Arrum Haji di Pegadaian Syariah Berdasarkan Fatwa DSN MUI Nomor 92 Tahun 2014(Studi pada Pegadaian Syariah Cabang Pasar Babakan Kota Tangerang)", (Skripsi S1 Fakultas Syariah dan Hukum Universitas Islam Negeri Syarif Hidayatullah Jakarta, 2018)

Website Badan Pusat Statistik https://www.bps.go.id/ (diakses 19 Januari 2021)

Website Otoritas Jasa Keuangan www.ojk.go.id (diakses 15 Januari 2021)

Website Pegadaian https://www.pegadaian.co.id/ (diakses 15 Januari 2021)

Wulan, Septi. "Perkembangan dan Pemikiran Uang dari Masa ke Masa".AnNisbah. Volume 03. Nomer 01 2016. Tulungagung.

UU No. 14 Tahun 1967 Tentang Pokok Pokok Perbankan

UU No. 7 Tahun 1992 Tentang Perbankan

UU No 10 Tahun 1998 Tentang Perbankan 